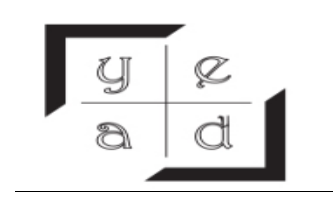

\title{
BÖLGESEL KALKINMA ÇALIŞMALARINDA ORTAK YAZARLIK VE ATIF AĞLARININ SOSYAL AĞ ANALİİ İLE İNCELENMESİ
}

Doç. Dr. Hakan DEMİRGíL *

\section{Dr. Öğr. Üyesi Süha ÇELIKKKAYA * iD}

\begin{abstract}
ÖZET
Sosyal ăg analizi ilişki yapılarının araştırılmasında kullanılan önemli bir yöntemdir. Aynı zamanda, bilimsel yayınların ilişki yapıları, işbirliği düzeyleri, üretken yazarların belirlenmesi, alıntı sayılarındaki durumun nitelik yönünden değerlendirilmesini sağlamaktadır. Bu çalışmada, Türkiye'de bölgesel kalkınma alanında yapılan çalışmalarda öne çıkan yazar ve bölümler, kurumsal işbirliği düzeyi sosyal ă̆ analizi ve düğümlerin ă̆ yapı içerisinde merkezilik değerleri yardımıyla incelenmektedir. 1975-2017 yılları arasında atıf indekslerinde (SCI, SSCI ve AHCI) Bölgesel Kalkınma konusunda, Türkiye adresli yapılmış 158 yayın değerlendirilmiştir.

Elde edilen sonuçlar, atıf indekslerinde yayınlanmış bölgesel kalkınma çalışmalarının hızının 2010 yllından sonra arttığını göstermektedir. Yapılan çalışmalar yeterli kurumsal desteğe sahip olmamakla birlikte, etki faktörü düşük dergilerde yayınlanmaktadır. Ayrıca, ekonomi bilimine ait bir çalışma alanı olmasına karşın, yayın sayısının şehir ve bölge planlama gibi diğer alanlarda daha yüksek olduğu görülmektedir..
\end{abstract}

Anahtar Kelimeler: Bölgesel Kalkınma, Sosyal Ă̆ Analizi, Bibliyometri, Kümelenme, Ağyapı.

JEL Kodları: R11, D85, C38.

\section{ANALYSIS OF COAUTHORSHIP AND CITATION NETWORKS IN REGIONAL DEVELOPMENT STUDIES WITH SOCIAL NETWORK ANALYSIS}

\begin{abstract}
Social network analysis is an important tool used to investigate relationship structures. Also, in terms of quality, it provides the evaluation of relationship structures of scientific publications, cooperation levels, determination of productive authors, and the situation in the number of citations. In this study, prominent authors and departmens and level of institutional cooperation in the field of regional development in Turkey are examined with the help of the social network analysis and centrality
\end{abstract}

* Süleyman Demirel Üniversitesi, İ.İ.B.F., Ekonometri Bölümü, Isparta/Türkiye, e-mail: hakandemirgil@ sdu.edu.tr

* Süleyman Demirel Üniversitesi, İ.İ.B.F., İktisat Bölümü, Isparta/Türkiye, e-mail: suhacelikkaya@sdu.edu.tr

Makale Geçmiși/Article History

Başvuru Tarihi / Date of Application : 29 Mayıs / May 2019

Düzeltme Tarihi / Revision Date 
measures of the nodes. Between the years 1975-2017, 158 articles, proceedings papers, reviews and materials of regional development studies addresing Turkey in the citation index (SCI, SSCI and AHCI) were evaluated.

The results show that the rate of regional development studies published in citation indexes increased after 2010. Studies do not have sufficient institutional support and also are published in journals with the low impact factor. In addition, although regional development studies belongs to economic science, it is seen that the number of publications is higher in other areas such as city and regional planning.

Key Words: Regional Development, Social Network Analysis, Bibliometrics, Cluster, Network.

JEL Codes: R11, D85, C38.

\section{GİRIŞ}

Küresel rekabetin var olduğu dünyada, 1950'li yıllardan kalma merkeziyetçi kalkınma kuramlarının yerine artık bölge kavramı üzerine kurulu kalkınma kuramları geçmiştir. Bölgesel ekonomilerde yaşanan bu önemli değişim neticesinde kalkınma kavramı ulusaldan bölgesel düzeye dönüşmüştür. Küreselleşmenin yoğunlaşmasıyla birlikte zıt bir eğilim olan yerelleşmenin görülmesi iktisadi kalkınma alanında çalışan araştırmacı ve akademisyenlerinde bu alana yönelmesine yol açmıştır.

$\mathrm{Bu}$ çalışma ile atıf indekslerinde bölgesel kalkınma çalışmalarının hangi alanlar üzerine yoğunlaştığı belirlenerek alanda yer alan yazarlar ve kurumlar arasındaki iş birliği ağ yapısının ortaya çıkartılması hedeflenmektedir. Böylece bölgesel kalkınma kavramında akademik performansa ilişkin bir görüş sunulması amaçlanmaktadır. Bu noktada bibliyometri çalışmaları, yayınların niteliği açısından değerlendirmeler sunarak araştırmaların gelişimi hakkında katkı sunmaktadır.

Çalışmada ilk olarak bölgesel kalkınmanın dönüşümü ve Türkiye'de bölgesel kalkınma kavramının seyri ele alınmaktadır. Daha sonra; bibliyometri ve sosyal ă analizi kavramlarına değinilmektedir. Son olarak; Türkiye adresli bölgesel kalkınma çalışmaları bibliyometrik özellikleri açısından sosyal ağ analizi yöntemiyle ele alınmaktadır. Çalışma değerlendirme ile son bulmaktadır.

\section{BÖLGESEL KALKINMANIN DÖNÜŞÜMÜ VE TÜRKİYE}

Bölge, iktisadi olarak bakıldığında "ülke kadar geniş, kent kadar da küçük olmayan bir yer parçası olarak tanımlanmıştır". Bununla birlikte farklı bilim, tanım ve kısıtlara bağlı olarak ele alındığında geçmişten itibaren değerlendirmek gerekirse üzerinde tam bir uzlaşı bulunamamıştır. Özellikle ulus devletlerin ortaya çıkışından sonra devletin içerisindeki farklı1ıklar ekonomik göstergelerle ele alınarak ulusal bütünleşmenin ana şartı ekonomik eşitsizliklerin giderilmesi olarak görülmüştür. Nitekim 1950'lerden itibaren kalkınma ekonomisinin güncellik kazanması ile bölgesel politikalar ve bölge planlama kavramlarının giderek daha fazla önemi haiz olmuştur (Eraydın, 2004: 126). 
İkinci Dünya Savaşı sonrası süreçte ortaya çıkan üretim patlaması modern tüketim toplumunun Kuzey Amerika ve Batı Avrupa'da yayılmasına yol açmıştır. Keynesyen refah devleti politikaları ile eş zamanlı olarak kent ve bölgelerde yaşanan şaşırtıcı derecedeki değişim ve gelişim akademisyenlerin el kitaplarında da yer etmiştir (Scott, 2000: 485-486).

Yakın zamana değin iktisatçılar tarafından dünya mekansal boyutu olmayan harikalar diyarı olarak ele alınmaktadır (Scott, 2000: 486). 20. yüzyılda yaşayan iktisatçılar olan Schumpeter ve Samuelson tarafından dahi mekan boyutunun ihmal edilmesi iktisat da bölge biliminin doğmasının nedenlerinden olmuştur (Yavan, 2007: 109-111). Bir tarafta William Garisson ve öğrencileri endüstriyel yerleşim yeri, arazi kullanım türleri, kentleşme ve merkezi yerleşim sistemleri gibi geniş bir yelpazeyi araştırırken diğer yandan Walter Isard ve diğer akademisyenler de iktisatçıların eleştirilerini dillendirmişlerdir (Scott, 2000: 486).

1970'lere gelindiğinde ise petrol krizleriyle birlikte dünya ekonomilerinde ortaya çıkan durgunluk geleneksel politikaların çöküşüne yol açmıştır. Bu dönemde esnek üretim gerçekleştiren küçük sanayi işletmeleri hızla gelişmiştir. "Yeni coğrafya" adını taşıyan ekonomik literatür ise bu dönemde oluşmuştur. Bretton Woods'un çöküşüyle başlayan "küresel ekonomi" ile iktisadi faaliyetler uluslararası bir hale gelirken ekonomiler giderek birbirlerine entegre olmuştur (Kumral, 2006: 275). Bölge; küreselleşen ekonomilerde rekabet üstünlüğü elde etmek için kullanılan bir kaynak haline gelmiştir (Amin, 1999: 368).

Krugman'a göre yeni ekonomik coğrafya kavramıyla ekonomilerdeki büyüme farklılıklarının anlaşılmasında bölge kavramının önemi büyüktür. Özellikle bölgesel büyümeden kaynaklı büyüme farklılıkları ve bölgesel uzmanlaşma kavramlarının önemi Krugman tarafından ifade edilmiştir (Krugman, 1991: 3).

Diğer yandan bakıldığında geleneksel bölgesel kalkınma politikalarına eleştiri olarak ortaya çıkan yeni bölgesel kalkınma politikaları küçük ve orta boy işletmeleri olduğu kadar akademik çevrelerde ulus devlet temelli yerel ve bölgesel politikalarında duyulmasına yol açmıştır (Moulaert ve Sekia, 2003: 290). Çok sayıda disiplinin ortak noktası olan bölgesel çalışmalar incelendiğinde ana odağın "bölgenin artan önemi" olduğu görülürken, bölgenin refah arttırmaya yönelik politikalardaki başarısı neticesinde bölgesel merkezli analizler karşımıza çıkmıştır (Dulupçu, 2006: 234-235).

Günümüzde bölgesel kalkınmanın gerçekleştirdiği gelişim ele alındığında toplumun neredeyse tüm alanlarında görülen değişmelerin etkisiyle şekillendiği görülmektedir. İlhan Tekeli bölgesel kalkınma sürecini "Sanayi toplumundan bilgi toplumuna geçiş, Fordist üretimden esnek üretime (postfordist) geçiş, Ulus devletlerin dünyasından küreselleşmiş dünyaya geçiş, Modernist düşünceden postmodernist düşünceye geçiş” olarak dörde ayırmıştır. Dünyada son 250 yılda meydana gelen değişmeler ele alındığında bu gelişmelerin toplumların refahını yükseltmek adına bölgelerde de yaşandığı görülmektedir (Tekeli, 1996: 24). 
Türkiye'de ki bölgesel kalkınma politikaları ele alındığında ise cumhuriyetin ilk yıllarından itibaren özellikle bölgeler arası gelir dağılımı adaleti konusunun irdelendiği görülmektedir. 1930'lu yıllarda Devletçi Dönemin eseri olarak 1.5 Yıllık Sanayi Planı ile başlayan bu süreç 1960'lı yıllarda D.P.T. tarafından hazırlanan kalkınma planları ile boyut atlamıştır. Planlı dönemde bölgesel gelişmişlik farkı daha çok dillendirilerek sorunların merkezinde yer almıştır. Bu süreçle beraber kapsamlı bir planlama benimsenirken ekonomik, sosyal ve kültürel gelişmenin arttırılmasına çalışılmıştır. Nitekim bölgelerarası kalkınma ilkesi, planlı kalkınmanın toplumsal hedefleri içerisinde yer almıştır (Sevinç, 2011: 44).

1980'e kadarki süreçte uygulanan ithal ikameci politikaların etkisi bölgesel kalkınmada da görülmüştür. Uygulanan politikalar ile bazı sanayi alanları gelişirken yatırımların büyük kısmı yapısı gereği köyden kente göçü tetiklemiştir. Türkiye'nin doğu ve batı bölgeleri arasındaki farklılık daha da belirginleşmiştir. Oluşan farklılıkların önüne geçebilmek maksadıyla 1968'de Kalkınmada Öncelikli Bölgeler kararı alınmakla birlikte uygulamada politikalar siyasilerin beklentilerine göre şekillendirilmiştir (Göymen, 2005: 2-3). 24 Ocak kararları sonrasında gelen neo-liberal politikalar ile bölgesel kalkınmada da ciddi değişimler yaşanmıştır. Küreselleşmenin ve liberalleşmenin etkisiyle DPT'nin politikalarında önemli dönüşümler görülürken Anadolu Kaplanları olarak ifade edilen bölgeler yükseliş kaydetmiş bazı bölgelerde ise körelmeler meydana gelmiştir.

Bölgesel politikalarda yaşanan köklü değişmeler ise 2000'li y1llarla birlikte görülmektedir. Bu dönemde, AB'ye üyelik için gerekli olan uyum sürecinin başlayabilmesi adına bölgesel alanda da bir takım düzenlemeler yapılmıştır. Yapılan düzenlemelerin en temelinde İstatistiki Bölge Birimleri Sinıflandırmas1 (IBBS) yer almaktadır (Keskin ve Sungur, 2010: 280). 28.08.2002 tarihli ve 2002/4720 sayılı kararname ile bölgesel istatistiklerin toplanması, geliştirilmesi, bölgelerin sosyo-ekonomik analizlerinin yapılması, bölgesel politikaların çerçevesinin belirlenmesi ve Avrupa Birliği Bölgesel İstatistik Sistemi'ne uygun karşılaştırılabilir istatistiki veri toplanması amacıyla ülke genelinde İstatistiki Bölge Birimleri Sınıflandırması tanımlanmıştır (T.C. Başbakanlık, 2002). İBBS 3 temel düzeyde alınmıştır. Düzey-1 12 bölge, Düzey-2 birbirlerine komşu olan 26 bölge ve Düzey-3 her il bir bölge olmak üzere 81 bölgeden oluşmuştur. İstatistiki Bölge Birimleri Sınıflandırması haricinde 2001 yılında Ulusal Program ve 2003 yılında Ön Ulusal Kalkınma Planı (ÖUKP) dökümanları da hazırlanmıştır. 2006 yılında yapılan düzenlemelerle birlikte 2008 ve 2009 senelerinde İBBS Düzey-2' de yer alan 26 bölgede Kalkınma Ajansları kurulmuştur. 2014 senesine gelindiğinde ise Bölgesel Gelişme Ulusal Stratejisi (BGUS) 2014-2023 yıllarına kapsayacak şekilde 10. Kalkınma Planı çerçevesinde hazırlanmıştır.

\section{BİBLIYOMETRİ}

1922'de E. Wyndham Hulme istatistiksel bibliyografyanın ulusal ve genel araştırma düzeyini tam olarak kapsamadığı düşüncesiyle bibliyometri kavramını ortaya atmıştır. Pritchard bibliyometriyi 
"Statistical Bibliography or Bibliometrics" isimli makalesinde günümüzdeki şekliyle tanımlamaktadır. Pritchard'a göre bibliyometri kitap ve diğer iletişim araçlarının matematiksel ve istatistiksel metodlar ile tatbik ettirilmesi olarak ifade edilmektedir (Pritchard, 1969: 347).

Bibliyometrik araştırmalar sayesinde literatürde yer alan çalışmaların yayım özellikleri incelenip çalışma kapsamına ilişkin yeni çıkarımlara ulaşılabilmektedir. Bu çıkarımlar ile araştırma yapılan alanın geçirmiş olduğu değişim görülebilmekte ve politika önerilerinde bulunulmaktadır.

Veri özellikleri ve veriyle ilgili süreçlerin ölçülmesini içeren bibliyometrik yöntemlerde atıf analizi, kelime sıklık analizi, ortak kelime analizi ile yazar, araştırma grubu veya bir ülkenin yayımladığı yayın sayılarına dair doküman sayımına ilişkin analizler yer almaktadır (Thelwall, 2008: 606).

Bibliyometri bir yazar, makale ya da derginin çeşitli atıf analizlerine dayalı bilimsel ağlarda ki konumunu ve etkisini ölçmeye yaramaktadır. Bu noktada alıntılar, uzmanlığın ya da yetkinin taşıyıcıları olarak hizmet ederler ve farklı açıklamalara karşılık gelirler. Bilimsel işbirliği ve doğrulama üç farklı analizden yararlanan iyi bilinen araştırma konularıdır. Bunlar; nitel analizler, bibliyometrik analizler ve kompleks ağ analizlerdir. Bu çalışmalarda küresel ağ çalışması özellikleri ya da bireysel ağ düğümlerinin sıralaması hakkında nicel analitik sonuçları ya da anket / gözlem sonuçlarının nitel içerik analizinden faydalanılmaktadır (Ding, 2011: 187).

\section{SOSYAL AĞ ANALİZi}

Sosyal ağ analizi $1988^{\prime}$ den itibaren farklı alanların yararlandığı bir analiz yöntemi olarak kullanılmaktadır (Rueda v.d, 2007: 2905). Görece yeni bir yöntem olan sosyal ağ analizi şu ana kadar Türkiye'de çok fazla uygulanmamakla birlikte son yıllarda yurt dışındaki eğilime benzer şekilde artan bir popülariteye sahiptir. Sosyal ağ analizine ilişkin artan ilgi hususunda kurumsal iktisat alanının da önemli payı bulunmaktadır.

Tanımlamak gerekirse, ăg yapı ve grafik kuramlarından yararlanarak sosyal yapıların araştırılması süreci sosyal ağ analizi olarak ifade edilmektedir (Otte, E. ve Rousseau, R., 2002). Sosyal ağ analizinden sosyal ağların incelenmesi ve analiz edilmesinde yararlanılmaktadır (Rueda v.d, 2007: 2905). Sosyal ağ; kişiler ve kurumlar arasındaki etkileşimi, bağları ve bağlantıları yansıtan yapı şeklinde ifade edilmektedir. Sosyal ağ analizi yöntemi birbirleriyle etkileşim içerisinde bulunan kümeleri bir ağ olarak görmekte ve bu ağların mevcut yapıları ile birbirlerine olan etkilerini ele almaktadır (Gürsakal, 2009: 184). Sosyal ağ analizinin ayrı bir özelliği de, yapısal düzenin aktörlerin davranışı üzerindeki etkiyi araştırmasıdır.

Literatürde sosyal ağları araştırma amaçlı ortaya konulan, bir strateji olarak da ifade edilen sosyal ağ analizi yapısal bir analizdir. Geleneksel yapıdaki birey tabanlı sosyal teori ve veri analizleri diğer oyuncu davranışlarını dikkate almadan tercihlerde bulunmaktadır. Bireyci yaklaşım aktörlerin sosyal bağlarını göz ardı etmektedir. Bu noktada sosyal ağ analizinde aktörler arasındaki ilişkiler ön planda 
bulunmakta ve ilişkisel veriler araştırmanın odağında yer almaktadır. Sosyal A $\breve{g}$ Analizinin bir diğer önemli yönü de, yapısal düzenlemelerin "oyuncuları" nasıl etkilediğinin araştırılmasıdır (Otte ve Rousseau, 2002: 441-442). Sosyal ăg analizi yöntemiyle ulaş1lan bilgilerle bilimsel yayın performansına yönelik araştırmalara katkı sağlanabilmektedir (Demirgil, 2018: 38).

A ̆g yapılarına bakıldığında belirli ortak özelliklerinin bulunduğu görülmektedir. Ding'e göre ağ yapılarının sahip olduğu bu temel özellikler belli başlıklar altında özetlenebilir. Bunlar şu şekilde suralanabilir;

Etkileşim grafikleri (ortak yazar ağları),

Kim kiminle görüşüyor/tanışıyor grafikleri (eposta iletişim ağları),

Bilgi bağlantı grafikleri (Atıf ağları),

Teknolojik ağlar (Eşler arası ağlar) (Ding, 2011: 187).

Sosyal ağ analizinde her aktör bir düğüm olarak bulunmaktadır. Dügümmler arasındaki bağlar ise köşelerdir. Düğümler ile bağların oluşturduğu ortamda dügümmler arasındaki önem derecesinin belirlenmesi ve hangi düğümün merkezde yer aldığının tespit edilebilmesi için temel merkezilik ölçüleri kullanılmaktadır (Demirgil, 2018: 39).

\section{YÖNTEM}

Sosyal ağ analizi yöntemi uygulanan çalışmalarda yazar ve kurum işbirliğinde öne çıkan ve bilgi akışında önemli pozisyona sahip kişi ve kurumların tespit edilebilmesi için yakınlık merkezilik, aradalık merkezilik ve derece merkezilik değerlerinden yararlanılmıştır. Çalışmada ağ yapı haritaları ve merkezilik değerleri CiteSpace ve UCINET programları kullanılarak elde edilmiştir.

Yakınlık Merkezilik: Yakınlık merkeziliği ağdaki tüm aktörlerin yapısal konumlarını dikkate almaktadır. Diğerleri arasında en kısa yola sahip olan aktör merkezdedir. A ̆ yapısında en merkezdeki mesaj en kısa sürede tüm ağa ulaşmaktadır ve merkezi bir tanedir (Codal ve Coşkun, 2016: 149). Yakınlık merkeziliği 1 numaralı formül ile belirlenmektedir. $\mathrm{d}\left(\mathrm{n}_{\mathrm{i}}, \mathrm{n}_{\mathrm{j}}\right)$ değerleri $\mathrm{n}_{\mathrm{i}} \mathrm{ve}_{\mathrm{j}} \mathrm{n}_{\mathrm{j}}$ köşeleri arasındaki uzaklığ göstermektedir.

$$
C_{D}=\left[\sum_{j=1}^{g} d\left(n_{i}, n_{j}\right)\right]^{-1}
$$

Aradalık Merkezilik: Bu ölçü, bir oyuncudan geçen en kısa yol sayısına dayanmaktadır. Kümelenme içindeki aktörün merkeziliğini göstermek için kullanılmaktadır. Farklı aktörler arasında yüksek aradalık değerine sahip olan aktör merkezde yer almaktadır. Aradalık merkeziliği 2 numaralı formül ile belirlenmektedir. Bir noktanın diğer noktalar ile arasındaki en kısa mesafe jeodezik uzaklık olarak tanımlanmaktadır. gjk jk arasındaki jeodezik bağlantı sayısını $g_{j k}\left(n_{i}\right)$ i aktörüne bağlı olarak jk arasındaki jeodezik bağlantı miktarını belirtmektedir (Demirgil, 2018: 39). 


$$
C_{B}=\sum_{j<k}^{n} g_{j k}\left(n_{i}\right) / g_{j k}
$$

Derece Merkezilik: Merkezilik çalışmalarından bir diğeri de derece merkeziliktir. Derece merkezlik bir aktörün (bir düğüm) diğer aktörlerle sahip olduğu bağlantı sayısına eşittir. Bir ağ yapısında merkezi yazar konumunda olmak, yazarın pek çok kişiyle işbirliği (ortak yazarlık) içerisinde bulunduğunu göstermektedir (Otte ve Rousseau, 2002: 447). Derece merkezilik değeri 3 numaralı formül ile hesaplanmaktadır.

$$
C_{d}(G)=\frac{\sum_{j=1}|v| C_{D}\left(V^{*}\right)-C_{D}\left(V^{j}\right)}{\max \sum_{j=1}|v| C_{D}\left(V^{*}\right)-C_{D}\left(V^{j}\right)}
$$

$\mathrm{CD}_{D}\left(\mathrm{~V}^{*}\right)$ ağ yapısındaki en yüksek merkezilik derecesini taşıyan düğümü ifade etmektedir. $\mathrm{C}_{\mathrm{D}}\left(\mathrm{V}_{\mathrm{j}}\right)$ ise her vj düğümünün merkezilik değerini belirtir.

\section{LITERATÜRE YÖNELIKK BAKIŞ}

Bibliyometrik çalışmaların geçmişi incelendiğinde Türkiye'de ilk kez Özinönü’nün 1970 tarihli çalışmasıyla başladığı görülmektedir (Özinönü, 1970). Bu tarihten sonra Türkiye'de çok sayıda bibliyometrik çalışma yayımlanmıştır. Zamanla giderek popülerleşen bibliyometrik çalışmaların kapsamları da süreç içinde genişlemiştir. Türkiye'de Sosyal Ağ Analizi yöntemi kullanılarak hazırlanan bibliyometrik araştırmaların ise salt bibliyometrik çalışmalara nazaran daha az olduğu görülmektedir. Bu durumda Sosyal Ağ Analizi yönteminin görece yeni olmasının da etkisi bulunmaktadır. Tabloda da belirtildiği üzere Türkiye'de Sosyal A $\breve{g}$ Analizi yöntemi ile hazırlanan ilk bibliyometrik makale 2008 yılında yayımlanmıştır. Diğer yandan çalışmanın kapsamı olan "bölgesel kalkınma" alanına ilişkin literatürde gerek doğrudan bibliyometrik, gerekse de sosyal ağ analizi yöntemi ile yapılan herhangi bir çalışma bulunmamaktadır. Tablo 1'de Türkiye'de sosyal ağ analizi yöntemi kullanılarak hazırlanan bibliyometrik çalışmalar yer almaktadır.

\begin{tabular}{|c|c|c|c|}
\hline Yazarlar & $\begin{array}{l}\text { Çalışma } \\
\text { Dönemi }\end{array}$ & Çalışma Adı & $\begin{array}{l}\text { İncelenen } \\
\text { Çalıșma Sayısı }\end{array}$ \\
\hline Birinci (2008) & $1995-2007$ & $\begin{array}{lll}\text { Turkish Journal of Chemistry'nin } \\
\text { Bibliyometrik Analizi }\end{array}$ & 861 Makale \\
\hline $\begin{array}{l}\text { Al, Soydal - } \\
\text { Yalçın (2010) }\end{array}$ & $2008-2010$ & $\begin{array}{l}\text { Bibliyometrik Özellikleri Açısından Bilig'in } \\
\text { Değerlendirilmesi }\end{array}$ & 100 Makale \\
\hline $\begin{array}{l}\mathrm{Al}-\text { Doğan } \\
(2012)\end{array}$ & 1974-2011 & $\begin{array}{l}\text { Hacettepe Üniversitesi Bilgi ve Belge } \\
\text { Yönetimi Bölümü Tezlerinin Attf Analizi }\end{array}$ & $\begin{array}{l}157 \text { Yüksek Lisans } \\
\text { ve Doktora Tezi }\end{array}$ \\
\hline $\begin{array}{l}\text { Al, Sezen - } \\
\text { Soydal (2012) }\end{array}$ & 1968-2009 & 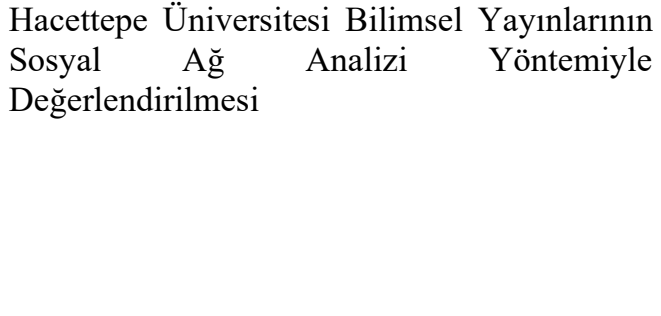 & $\begin{array}{l}\text { 13894 Makale } \\
2083 \text { Bildiri } \\
1613 \text { Mektup } \\
1576 \text { Eleştiri, } \\
\text { Kisa } \\
\text { Editoryal, } \\
\text { İnceleme } \\
\text { Düzeltme }\end{array}$ \\
\hline
\end{tabular}

Tablo 1. Türkiye'de Hazırlanan Bibliyometrik Çalışmalar 
Yönetim ve Ekonomi Araștırmaları Dergisi / Journal of Management and Economics Research

Cilt/Volume: 17 Sayl/Issue: 4 Arallk/December 2019 ss./pp. 296-315

H. Demirgil, S. Çelikkaya Doi: http://dx.doi.org/10.11611/yead.571612

\begin{tabular}{|c|c|c|c|}
\hline $\begin{array}{l}\text { Karagöz - Kozak } \\
\text { (2014) }\end{array}$ & $1997-2010$ & $\begin{array}{l}\text { Anatolia Turizm Araştırmaları Dergisi’nin } \\
\text { Bibliyometrik Analizi: Araştırma Konuları ve } \\
\text { Kurumlar Arası İş Birliğinin Sosyal Ağ } \\
\text { Analizi ile İncelenmesi }\end{array}$ & 205 Makale \\
\hline $\begin{array}{l}\text { Besimoğlu } \\
(2015)\end{array}$ & 1996-2011 & $\begin{array}{l}\text { Türkiye'deki Ziraat Fakültelerinin Tarımsal } \\
\text { Araştırma Eğilimleri: 1996-2011 Yı1ları } \\
\text { Yaşam Bilimleri Veri Tabanı yayınlarının } \\
\text { Bibliyometrik Analizi }\end{array}$ & 7471 Makale \\
\hline $\begin{array}{l}\text { Sayğan Tunçay, } \\
\text { Süral Özer - } \\
\text { Tozkoparan } \\
\text { (2015) }\end{array}$ & 2002-2011 & $\begin{array}{l}\text { Yerel Yazında Sosyal Sermaye Araştırmaları: } \\
\text { Odaklar ve Boşlukların Sosyal A } \breve{g} \text { Analizi İle } \\
\text { İncelenmesi }\end{array}$ & 69 Makale \\
\hline $\begin{array}{l}\text { Turgut } \\
\text { Beğenirbaş } \\
(2016)\end{array}$ & 2013-2014 & $\begin{array}{l}\text { Türkiye'deki Örgütsel Davranış Yazınına } \\
\text { Bakış: Örgütsel Davranış Kongrelerinin Yazar } \\
\text { Ve İçerik Yönünden Ağ Analizi İle } \\
\text { İncelenmesi }\end{array}$ & $\begin{array}{l}174 \text { Sözel Bildiri } \\
15 \text { Poster Bildiri }\end{array}$ \\
\hline $\begin{array}{l}\text { Y1ldırım - Ergüt } \\
\text { (2016) }\end{array}$ & $2000-2014$ & $\begin{array}{l}\text { Kadına Yönelik Şiddet Araştırmaları: } 2000 \\
\text { Yılı ve Sonrası İçin Bibliyometrik Bir Analiz }\end{array}$ & 3155 Makale \\
\hline Demirgil (2018) & 1992-2016 & $\begin{array}{l}\text { Süleyman Demirel Üniversitesi Yayınlarında } \\
\text { Bilimsel Yoğunlaşma Alanları ve } \\
\text { Bibliyometrik Ağ Analizi }\end{array}$ & $\begin{array}{l}6452 \text { Makale } \\
444 \text { Bildiri } \\
326 \text { Özet Bildiri } \\
218 \text { Mektup } \\
106 \text { Derleme } \\
80 \text { Editöre Mektup } \\
33 \text { Düzeltme } \\
5 \text { Haber Başlığı } \\
3 \text { Kitap Kritiği }\end{array}$ \\
\hline $\begin{array}{l}\text { Güzeller } \\
\text { Çeliker (2018) }\end{array}$ & 2007-2016 & $\begin{array}{l}\text { Bibliometric Analysis of Tourism Research for } \\
\text { The Period 2007-2016 }\end{array}$ & 4473 Makale \\
\hline
\end{tabular}

\section{BULGULAR}

Web of Science, bibliyometri çalışmalarında en sık kullanılan veri kaynağıdır. Sanat ve beşeri bilimler, sosyal bilimler ve fen bilimleri alanındaki en saygın ve en etkin binlerce dergiyi bir araya getirmektedir. Veri tabanın kendisi üç alıntı endeksinden oluşmaktadır: Sanat ve Beşeri Bilimler Atıf İndeksi (A\&HCI), Sosyal Bilimler Atıf İndeksi (SSCI) ve Fen bilimleri Atıf İndeksi (SCI). Bu üç veri tabanının kendi içerisinde farklı kategoriler yer almaktadır. Çalışmada üç indekste 1975 ve 2018 yılları arasında yayımlanmış ve başlık, özet ve anahtar kelimelerinde "bölgesel kalkınma (regional development)" kelimelerini içeren ve yayın adresleri "Türkiye (Turkey)" olan çalışmalar incelenmektedir. Arama sonucunda 651 yayın elde edilmiştir. Ancak, Web of Science kategorilerine bakıldığında, yayınların önemli bir kısmının Yer Bilimleri, Çevre Bilimleri gibi alanlarda yapıldığı görülmektedir. Bu nedenle 651 yayın içerisinde ekonomi başta olmak üzere ilgili alanlar üzerinden bir filtreleme yapılmıştır. Seçilen Web of Science kategorileri; ekonomi (economics), alan çalışmaları (area studies), planlı kalkınma (planning development), kent çalışmaları (urban studies), işletme (business), yönetim (management), sosyal bilimler disiplinler arası (social sciences interdisciplinary), işletme finans (business finance), siyasal bilimler (political science) ve kamu yönetimi (public administration)’ dir. Bu filtreleme sonrasında değerlendirme yapılacak yayın sayısı 158 olarak elde edilmiştir. 
Tablo 2. Yayınların Türlerine Göre Dağılımı

\begin{tabular}{ll}
\hline Yayın Türü & Sayı \\
\hline Makale & 113 \\
Bildiri & 40 \\
Derleme & 4 \\
Editöre Mektup & 2 \\
\hline
\end{tabular}

Yayınların türlerine göre dağılımına bakıldığında, ağırlıklı olarak makale ve bildiri olduğu ve az sayıda derleme ve editöre mektup türünde yayın yapıldığı görülmektedir. Derleme ve editöre mektup türünde yayınların sayısı toplam içinde oldukça düşüktür.

\section{Grafik 1.Yayınların Yıllara Göre Dağılımı}

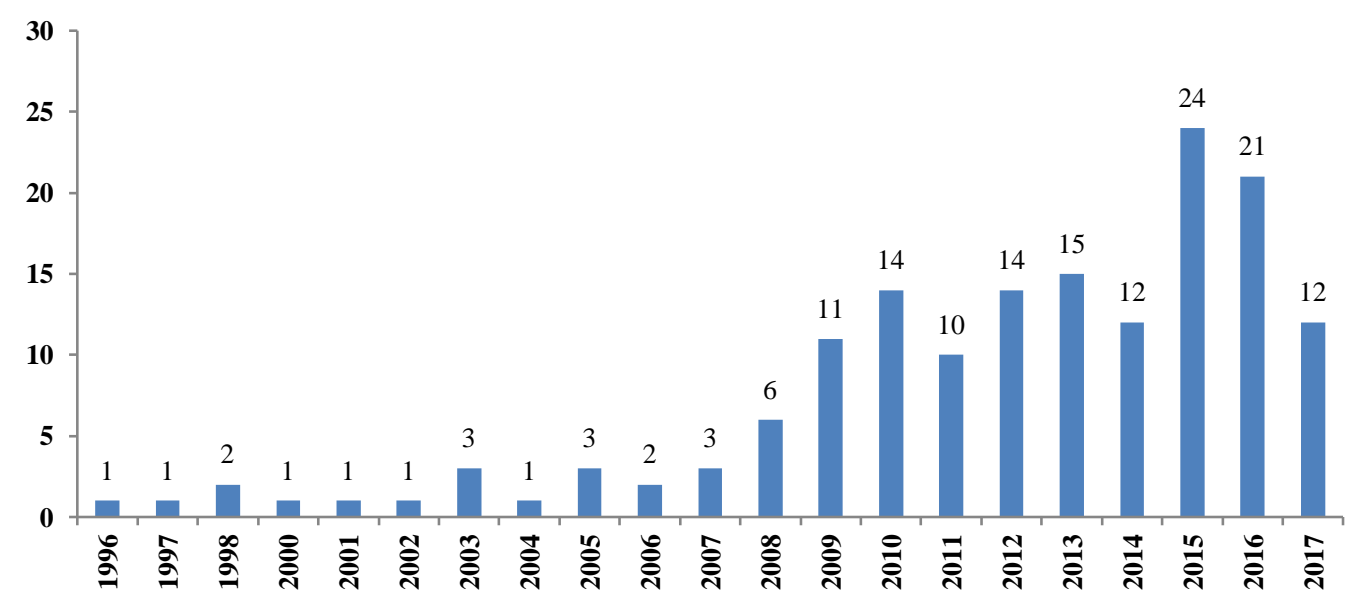

Grafik 1 yıllara göre yayınların dağılımını göstermektedir. Bölgesel kalkınma alanında Türkiye adresli yapılan ilk yayınlar 1966 ve 1997 yılında başlamaktadır. 2000'li yılların başında yapılan yayın sayısında ciddi bir değişim olmamakla birlikte, 2008 yılından sonra hızlı bir artış gözlemlenmektedir. 2015 yılında ise en yüksek yayın sayısına ulaşılmaktadır. Bölgesel kalkınma çalışmalarının güncellik kazandığ 12000 'li yılların başında, Türkiye üniversitelerinde ilginin düşük kaldığı ve araştırmacıların çalışmalarında atıf indekslerini tercih etmedikleri görülmektedir. 2010'lu yıllarla birlikte hızla artan bir ilgi ve atıf indeksli dergilerin tercih edilme sıklığında artış olduğunu göstermektedir.

Yayın sayısındaki büyüme hızının ölçülmesi amacıyla kurulan doğrusal regresyon modeline ait sonuçlar aşağıda yer almaktadır.

$$
b k(t)=-3.605+1.011 t
$$

(4) nolu denklemde $t$ ilk atıf indeksli yayının yapıldığı 1996 yılında $\mathrm{t}=1$ olmak üzere trend değişkenini, $b k(t)$ t'nin bir fonksiyonu olarak yayın sayısını göstermektedir. Modelin belirlilik katsayısı (r2) 0.764 ve korelasyon katsayısı (r) 0.874 'e eşittir. Modelin sabit terim ve eğim katsayısı istatistiksel olarak anlamlı tahmincilerdir (sırasıyla t istatistikleri -2.226 ve $7.847^{\prime}$ dir). Bu sonuçlar bölgesel 
kalkınma alanındaki atıf indeksli yayınların sayısındaki artış ve zaman değişimi arasında güçlü bir ilişkinin olduğunu göstermektedir.

$$
b k(t)=0.6133 \mathrm{e} 0.1758 t
$$

Yayın sayısı ve zaman değişimi arasındaki ilişkiyi tanımlayan en iyi işlev kalıbı ise üstel fonksiyondur. (5) nolu denklem üstel fonksiyona ait tahmin sonuçlarını göstermektedir. Modelin belirlilik katsayısı $\left(\mathrm{R}_{2}\right) 0.851$ ve korelasyon katsayısı $(\mathrm{r})$ 0.922'ye eşittir ve model doğrusal fonksiyona göre daha iyi bir uyum ölçütüne sahiptir. Bu sonuçlar, zaman içerisinde ilk yıllarda yayın sayısındaki artış hızının düşük olduğunu, 12. ve 13. dönemlerden sonra ayın sayısındaki artış hızının yükseldiğini göstermektedir. Doğrusal ve üstel fonksiyona ait tahmin eğrileri grafik 2'de yer almaktadır.

\section{Grafik 2. Yıllara Göre Yayın Sayısındaki Artış}

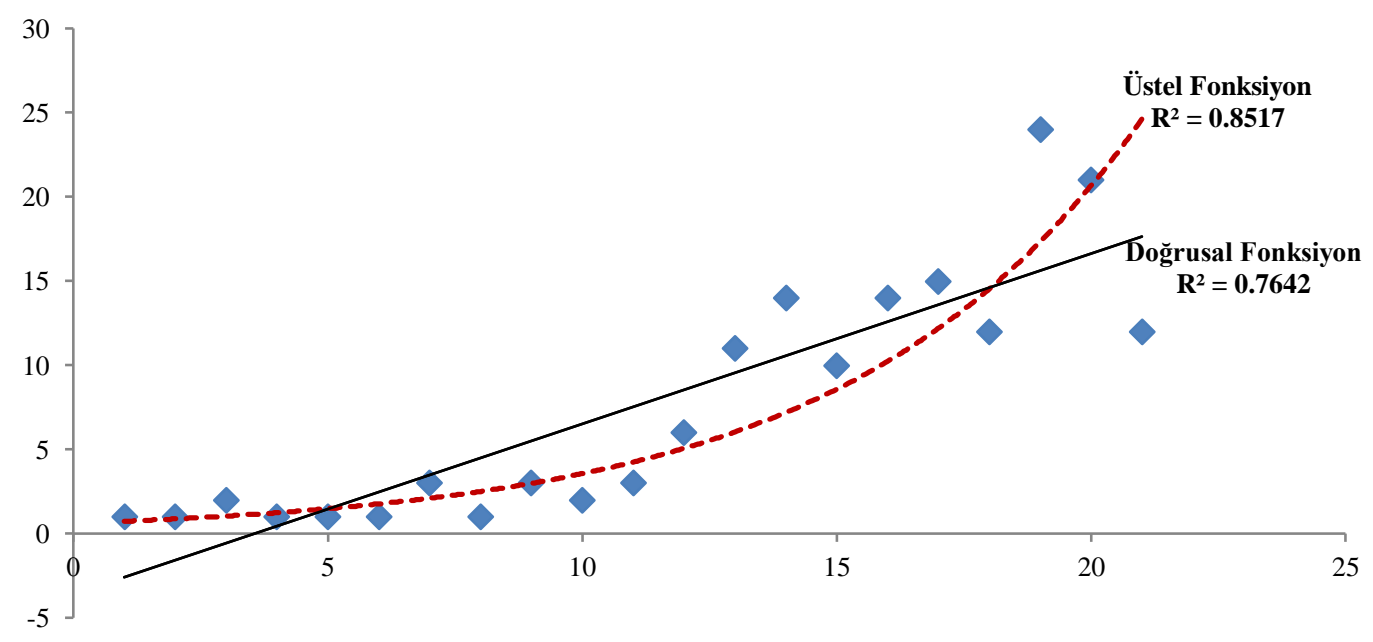

Alanda yapılan atıf indeksli yayınların kümülatif yayın sayısındaki artış, 1996 yılından başlayarak incelenmiştir. Üç farklı fonksiyona ait tahmin eğrileri grafik 3 'te görülmektedir.

\section{Grafik 3. Yıllara Göre Yayın Sayısındaki Artış}

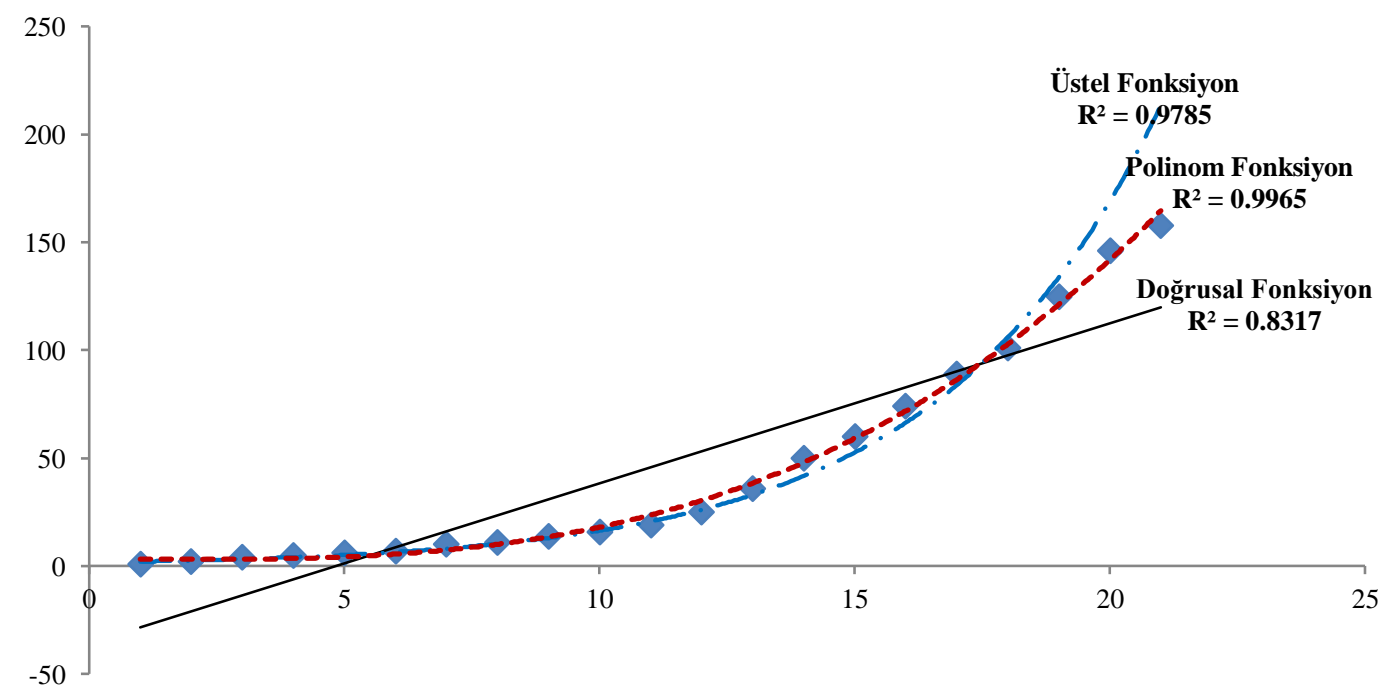


Kümülatif yayın sayısı ve zaman değişimi arasında polinom fonksiyonel ilişkinin daha iyi uyum ölçütüne $\left(\mathrm{R}_{2}=0.978\right)$ sahip olduğu görülmektedir. Polinom denkleme ait tahmin sonuçları aşağıda ye almaktadır:

$$
k \_b k(t)=0.0192 t 3-0.0296 t_{2}-0.1561 t+3.3308
$$

(6) nolu denklemde $k \_b k(t)$ kümülatif yayın sayısını göstermektedir. Yıllar itibariyle kümülatif yayın sayısındaki artış ve zaman değişimi arasında polinom bir fonksiyonel ilişkinin olması, belirli dönemlerde yayın sayılarında artış hızının farklılık gösterdiğine işaret etmektedir. Dönemsel yayın sayısında olduğu gibi, kümülatif yayın sayısında üstel bir artış hızının beklenmesine karşın, belirli dönemlerde artış hızının düşmesi, yayın performansının kurumsal desteklerin sağlanması gibi faktörlerden etkilenebileceğine işaret etmektedir.

Tablo 3. Kurumsal Destek Alan Çalışmalar

\begin{tabular}{ll}
\hline Destekleyen Kuruluş & Sayı \\
\hline İTÜ Araştırma Fonu & 1 \\
İzmir Bölgesel Kalkınma Ajansı İZKA & 1 \\
TÜBİTAK & 1 \\
Artvin Çoruh Üniversitesi Bilimsel Araştırma Konseyi & 1 \\
Uludağ Üniversitesi BAP & 1 \\
\hline
\end{tabular}

Tablo 3'de görüldüğü üzere, toplam 5 yayın ulusal kuruluşlarca desteklenen çalışmalar sonucunda üretilmiştir. Bölgesel kalkınma alanında sadece ulusal değil aynı zamanda uluslararası kurumsal desteklerin artırılması yapılan çalışmaların sayı ve niteliğinin artmasına önemli katkı sağlayacaktır.

Tablo 4. Yayınların Dergilere Göre Dağglımı

\begin{tabular}{ll}
\hline Dergi & Sayı \\
Turkish Studies (1,029) & 10 \\
European Planning Studies (1,332) & 8 \\
İktisat İşletme ve Finans & 8 \\
Journal of Balkan and Near Eastern Studies (0,981) & 8 \\
Procedia Social and Behavioral Sciences (0,40) & 8 \\
World Conference on Technology Innovation and Entrepreneurship & 6 \\
Bilig (0,098) & 5 \\
Regional Studies (2,78) & 5 \\
Southeast European and Black Sea Studies (0,339) & 5 \\
Amme İdaresi Dergisi (0,07) & 4 \\
Annals of Regional Science (0,694) & 4 \\
European Urban and Regional Studies (2,077) & 4 \\
Middle East Journal (0,49) & 3 \\
Planlama-Planning & 3 \\
Turkish Policy Quarterly & 3 \\
\hline
\end{tabular}

Not: Parantez içerisindeki değerler, dergilerin etki faktörleridir. 
Bölgesel kalkınma alanında Türkiye adresli yapılan 158 yayın 96 farklı dergide yayınlanmıştır. En çok çalışmanın yayınlandığı ilk 15 dergi Tablo 4'te yer almaktadır. En çok çalışmanın yayınlandığı dergi “Turkish Studies" dir. "European Planning Studies", "Regional Studies" ve "European Urban and Regional Studies" gibi bölgesel kalkınma alanında önemli ve etki değeri birden büyük dergilerdeki makale sayısı 17' dir (Toplam yayınların yaklaşık \%10'u). Ayrıca, Makalelerin yayınlandığı dergilerden dördünün etki faktörü birden büyüktür. Çalışmaların büyük bir kısmının atıf alma oranı düşük dergilerde yoğunlaştı̆̆ anlaşılmaktadır.

\section{Şekil 1. Dergilerin Ăg Haritası}

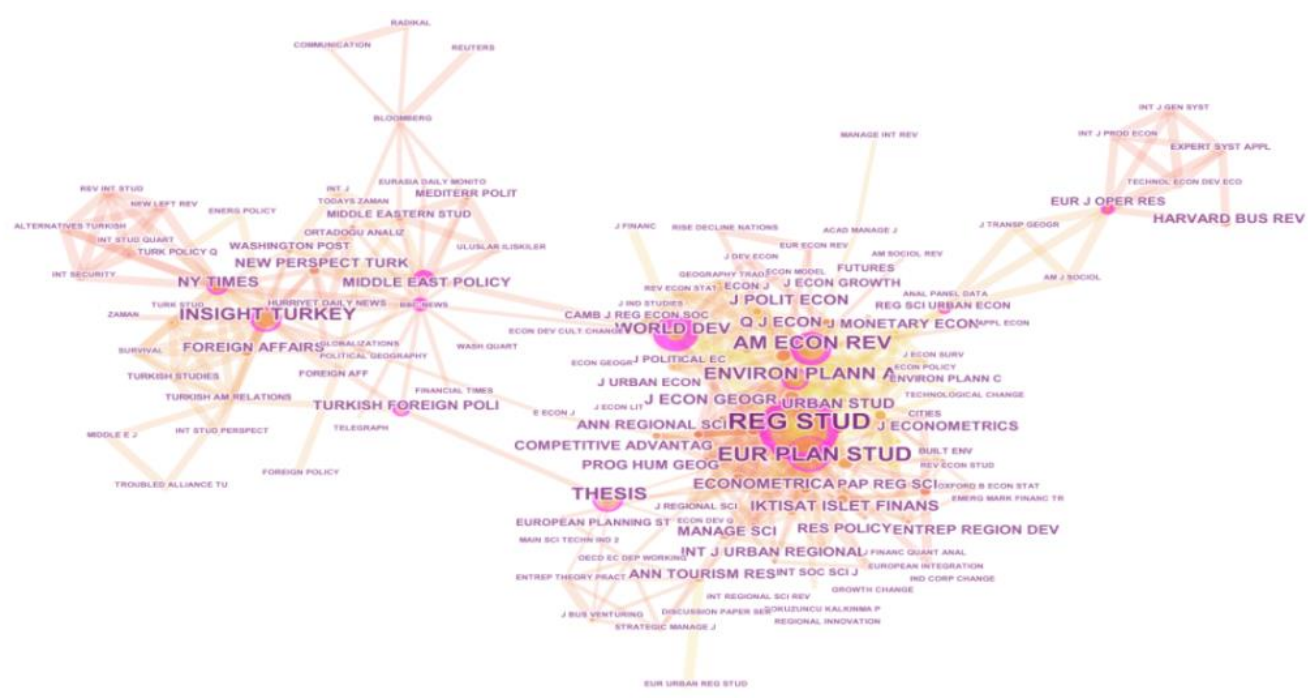

Şekil 1'de çalışmaların yayınlandığı dergilerin ağ haritası görülmektedir. Haritanın sol tarafındaki kümelenme bölgesel kalkınma konulu çalışmaların yayınlandığı uluslararası ilişkiler alanındaki dergilerden oluşmaktadır. Sağ tarafta yer alan kümelenme ise ekonomi dergilerine aittir. En çok atıf alan makalelerin yayınlandığı dergilerin "European Planning Studies", "Regional Studies" ve "Insight Turkey” olduğu görülmektedir. Bu dergiler ağ yapının merkezinde yer almaktadır.

Tablo 5. Yayınların Kurumlara (Yurtiçi) Göre Dağılımı

\begin{tabular}{ll}
\hline Kurum & Sayı \\
\hline İstanbul Teknik Üniversitesi & 14 \\
ODTÜ & 11 \\
Bilkent Üniversitesi & 10 \\
Bahçeşehir Üniversitesi & 6 \\
Dokuz Eylül Üniversitesi & 6 \\
İstanbul Üniversitesi & 6 \\
Uludağ Üniversitesi & 6 \\
Ankara Üniversitesi & 5 \\
Çanakkale Onsekiz Mart Üniversitesi & 5 \\
Ege Üniversitesi & 5 \\
Kadir Has Üniversitesi & 5 \\
Sabancı Üniversitesi & 5
\end{tabular}




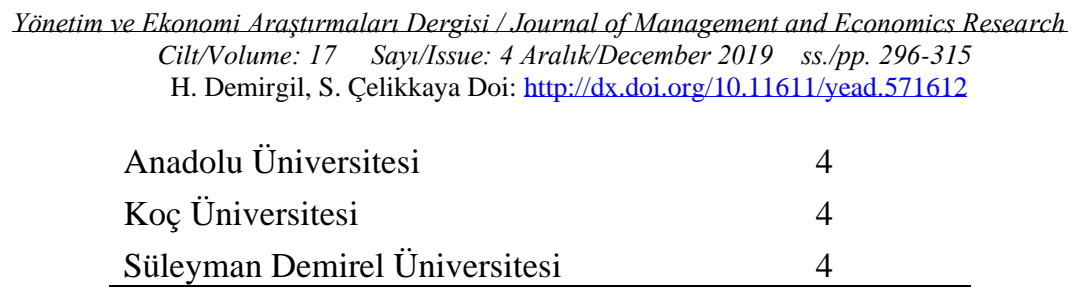

Türkiye'de bölgesel kalkınma çalışmalarında en fazla çalışmayı yapan kurum İstanbul Teknik Üniversitesi'dir. 10 ve daha fazla çalışmaya sahip diğer kurumlar ODTÜ ve Bilkent Üniversiteleridir. Bu üniversitelerin Şehir ve Bölge Planlama bölümlerinde bölgesel kalkınma alanında yapılan çalışma sayısı yüksek olduğundan, alanda yayın sayısında ilk sırada olmalarını sağlamaktadır. En çok yayın yapan kurumların büyükşsehir üniversiteleri ve vakıf üniversiteleri olduğu görülmektedir. Bölgesel kalkınma konusuna daha fazla önem verilmesi gereken Anadolu üniversitelerinden sadece Çanakkale Onsekiz Mart ve Süleyman Demirel Üniversiteleri en çok yayın yapan kurum sirlamasında yer almaktadır.

Tablo 6. Yayın İşbirliğinde Ülkeler

\begin{tabular}{ll}
\hline Ülke & Sayı \\
\hline ABD & 9 \\
Hollanda & 4 \\
İngiltere & 3 \\
Kanada & 1 \\
Finlandiya & 1 \\
Fransa & 1 \\
Almanya & 1 \\
Macaristan & 1 \\
Japonya & 1 \\
Yeni Zelanda & 1 \\
Çin & 1 \\
Polonya & 1 \\
Katar & 1 \\
İspanya & 1 \\
\hline
\end{tabular}

Yapılan çalışmalarda yurt dışında çalışan ortak yazarların ülkelerine bakıldığında, batı ülkelerinin ağırlıkta olduğu görülmektedir. Asya ve Orta Doğu ülkeleri ile bölgesel kalkınma çalışmalarının artma potansiyeli yüksektir. Bu bölgelerdeki kurumlar ile yapılacak işbirliklerin artırılması, yayın sayısının yükselmesine katkı sağlayacaktır. 
Tablo 7. En Fazla Yayına Sahip Yazarlar

\begin{tabular}{ll}
\hline Yazar & Sayı \\
\hline Tüzin BAYCAN (Şehir ve Bölge Planlama) & 6 \\
Sedef AKGÜNGÖR (Ekonomi) & 3 \\
Oğuz ÖZBEK (Şehir ve Bölge Planlama) & 3 \\
Aliye Ahu AKGÜN (Şehir ve Bölge Planlama) & 2 \\
Meliha Benli ALTUNIŞIK (Uluslararası İlişkiler) & 2 \\
Mert BİLGİN (Uluslararası İlişskiler) & 2 \\
Melih BULU (İ̧letme) & 2 \\
Orhan DEMİR (Şehir ve Bölge Planlama) & 2 \\
Vedia DÖKMECİ (Şehir ve Bölge Planlama) & 2 \\
Tanyel Özelçi ECERAL (Şehir ve Bölge Planlama) & 2 \\
Yaprak GÜLCAN (Ekonomi) & 2 \\
Serhat GÜVENÇ (Uluslararası İlişkiler) & 2 \\
Fuat KEYMAN (Siyaset Bilimi) & 2 \\
Bilge Armatlı KÖROĞLU (Şehir ve Bölge Planlama) & 2 \\
Yeşim KUŞTEPELİ (İşletme) & 2 \\
\hline
\end{tabular}

En çok yayın sayısına sahip ilk 15 yazar ve hangi bölümde görev yaptıkları Tablo 7'de yer almaktadır. Türkiye'de bölgesel kalkınma alanında en çok atıf endeksli yayına sahip olan yazar Tüzin Baycan'dır. Tablo'da dikkat çeken nokta ise, bölgesel kalkınmanın ekonomi bilimi altında bir çalışma alanı olmasına karşın, en çok yayına sahip yazarların ağırlıklı olarak Şehir ve Bölge Planlama bölümlerinde çalıştıkları görülmektedir. Uluslararası İlişkiler, Siyaset Bilimi ve İşletme bölümlerinde görev yapan yazarların da bölgesel kalkınma alanında atıf indekslerinde yayımlanmış dergilerde çalışmalara sahiptir. Bölgesel kalkınma alanında ekonomi ve iktisat bölümlerinde çok sayıda akademisyenin bireysel ve proje çalışmaları yürütülmekte ve lisansüstü programlarda tez çalışmaları yapılmakla birlikte, bu çabaların atıf indekslerinde nitelikli yayınlara dönüşmediği anlaşılmaktadır.

Tablo 8. Yazarların Merkezilik Değerleri

\begin{tabular}{llll}
\hline & Degree & Closenes & Betweenness \\
\hline Meliha Benli ALTUNIȘIK & 3.985 & 343.000 & 207.634 \\
Alpay FİİZTEKİN & 3.000 & 330.000 & 780.614 \\
Bülent DİNÇER & 3.000 & 447.000 & 65.533 \\
Tüzin BAYCAN & 3.000 & 365.000 & 87.107 \\
Metin BERBER & 2.500 & 448.000 & 65.333 \\
İlhan TEKELİ & 2.233 & 345.000 & 178.814 \\
Kemal KİRİSĊİ & 2.168 & 346.000 & 13.587 \\
\hline
\end{tabular}

Yazar işbirliği ağında öne çıkan ve bilgi akışında önemli konuma sahip olan kişilerin belirlenmesi amacıyla aradalık, yakınlık ve derece merkezilik değerleri kullanılmıştır. Yazarların merkezilik değerlerine bakıldığında (Tablo 8), sahip olduğu yayın ve atıf sayısına göre derece merkeziliği en yüksek yazar Meliha Benli ALTUNIŞIK'dır. Bir düğümün ağ yapı içerisindeki diğer düğümlerle bağlantı 
sayısının fazla olması, merkezi bir konumda olduğunu gösterebilir. Fakat bağlantılı olduğu düğümlerin ağ yapı içerisinde dağınık konumda olmaları, ilişki yapısının kısıtlı olduğuna gösterecektir. Bu nedenle, düğümün sahip olduğu bağlantı sayısını gösteren derece merkeziliği yanında, yakınlık ve aradalık ölçütlerini de kullanarak ağ yapı küme içerisindeki avantajlı konumunu değerlendirmek daha yararlı olacaktır. Metin BERBER ve Bülent DİNÇER yakınlık değeri en yüksek olanlar yazarlardır ve bu yazarların sahip olduğu bağlantıların yapısı, ağ yapı içerisindeki diğer yazarlara daha hızlı ve en kısa yoldan ulaşma avantajı sağlamaktadır. Özellikle aldıkları atıflar sayesinde bölgesel kalkınma alanındaki bilgi akışını izleyebilecekleri en iyi konuma sahiptirler. Aradalık ölçütü, bir dügü̈mden geçen en kısa yol sayısına dayanmaktadır. Aradalık değeri yüksek olan düğümler, arabulucular olarak farklı grupları birbirine bağlama rolünü oynarlar. Ağ içerisindeki bir düğümün yüksek aradalık değerine sahip olması onun yapı içerisindeki ilişkiler üzerinde en fazla etkiye sahip olduğunu göstermektedir. Yazalar arasında en yüksek aradalık değerine ve ağ yapı içerisinde en etkili olan kişi Alpay FİLİZTEKİN'dir.

\section{Şekil 2. Yazar Atıf A $\breve{g}$ Haritası}

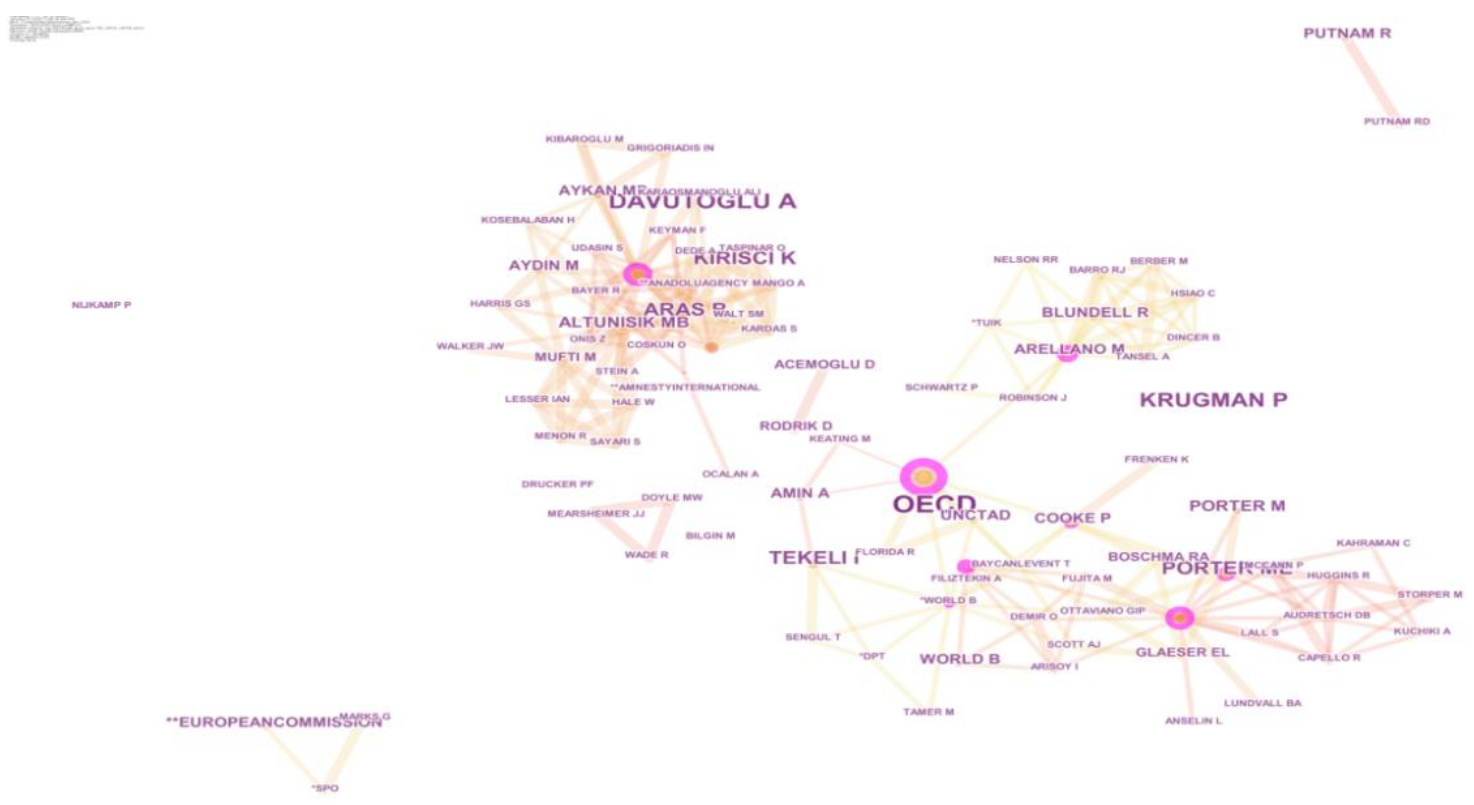

A $\breve{g}$ haritasında Türkiye adresli bölgesel kalkınma çalışmalarında en çok atıf alan yazarların Michael PORTER, Ahmet DAVUTOĞLU ve OECD’nin yapmış olduğu yayınlar olduğu görülmektedir. Yazarların atıf değerlendirmeleri, Türkiye'de bölgesel kalkınma çalışmalarının uluslararası ilişkiler alanı ile bir kesişmeye sahip olduğuna işaret etmektedir. Meliha Benli ALTUNIŞIK ve Kemal KİRIşÇİ gibi merkezilik değerleri yüksek yazarların uluslararası ilişkiler bölümlerinde görev yaptığ1 görülmektedir. Aynı zamanda şehir ve bölge planlama bölümlerinde görev yapan İlhan TEKELİ ve Tüzin BAYCAN gibi yazarlarda yüksek merkezilik değerlerine sahiptir.

Bölgesel kalkınma alanında yapılan çalışmalarda öne çıkan grupları belirlemek ve hangi çalışma konularının bir arada alt bir grup oluşturduğunu ortaya çıkarmak amacıyla kümelenme analizi 
uygulanmıştır. Buna göre, araştırma alanı ağında toplam dört adet küme ortaya çıktığı görülmektedir (Bkz: Şekil 3).

Şekil 3. Bölgesel Kalkınma Çalışmalarında Yazar Ă̆ Yapısına Ait Kümelenmeler

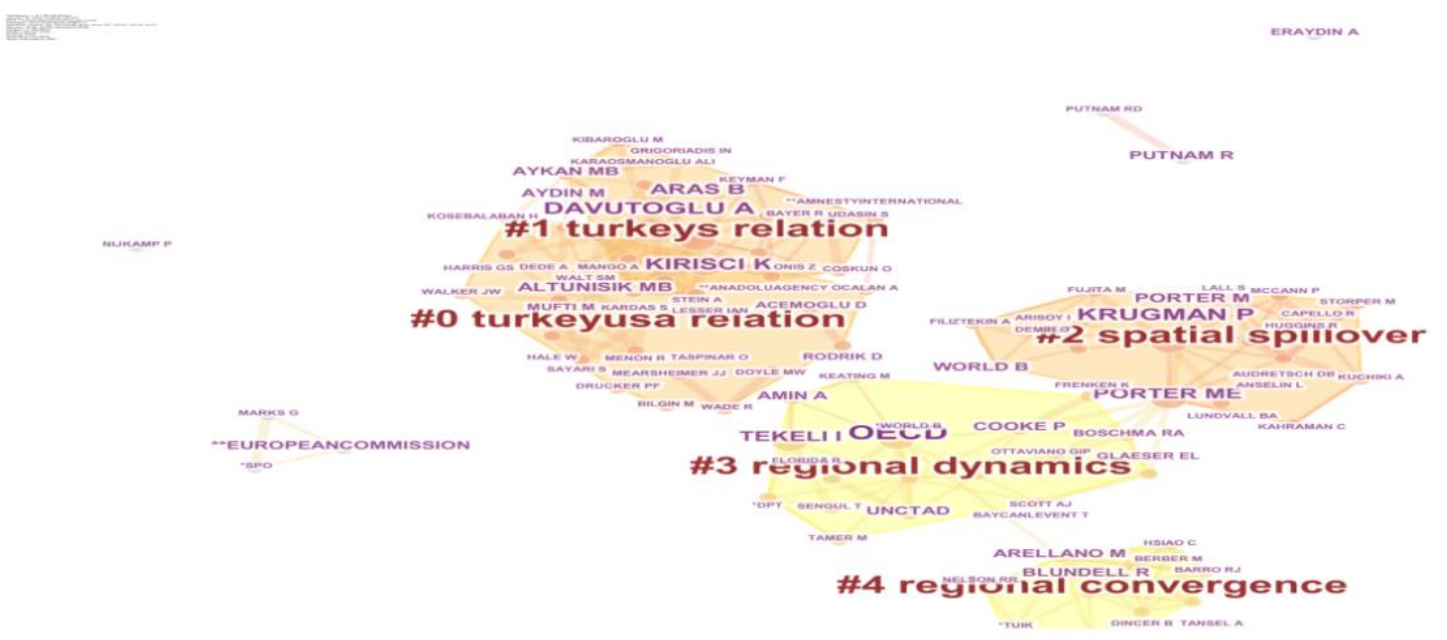

Modularity değeri pozitif veya negatif değerler alabilir. Bu değer küme içerisinde yer alan düğümlerin bir araya gelmesinin uygunluğunu belirlemek için kullanılmaktadır. Pozitif ve yüksek Modularity değeri küme içerisinde üyelerin doğru bir şekilde yer aldığını göstermektedir. Formülü,

$$
Q=\sum_{i=1}^{k}\left(e_{i i}-a_{i}^{2}\right)
$$

A ̆g yapıya ait Modularity Q değeri 0.6915 olarak hesaplanmıştır. Bu pozitif değer ağın birbiriyle uyumlu düğümlerden oluşan kümelere ayrıldığını göstermektedir. Kümeleme analizi sonrasında, bir düğümün içinde yer aldığı kümeye uygunluğunu belirleyen ölçüt Silhouette değeridir. Bu değer +1 ve 1 arasında yer almaktadır. Silhouette değerinin artması düğümün kendi kümesine uygun bir birim olduğunu göstermektedir.

Formülü;

$$
\mathrm{S}=\frac{\mathrm{b}-\mathrm{a}}{\max (\mathrm{a}, \mathrm{b})}
$$

Silhouette değeri 0.58 'e eşittir ve düğümlerin yer aldığ kümeye uygun olduğunu ve kümelerin homojenliğinin sağlandığını göstermektedir. Birinci kümede 20, ikinci kümede 19, üçüncü kümede 18, dördüncü kümede 17 ve beşinci kümede 11 yazar yer almaktadır.

Tablo 9'da kümelerin düğüm sayısı, Silhouette değerleri ve kümelerde yer alan yer alan çalışmalarda en çok kullanılan anahtar kelimeler yer almaktadır. Her kümeye ait Sihouette değerleri 1'e yakın ve yüksektir. En büyük ilk iki kümelenmenin anahtar kelimeleri, bu kümelenmelerin uluslararas1 ilişkiler alanına ait olduğunu göstermektedir. En büyük ölçeğe sahip küme içerisindeki yayınlarda sık kullanılan anahtar kelimeler sirasiyla "turkeyusa relation", "new direction", "turkeys relation", "main argument" ve "bilateral ties" şeklindedir. diğer kümelenmelere ait anahtar kelimeler incelendiğinde, bu 
kümelenmelerin iktisat, şehir ve bölge planlama ve siyaset bilimi alanlarına ait olduğu anlaşılmaktadır. $\mathrm{Bu}$ alanlarda öne çıkan çalışma konuları ise mekânsal yayılma (spatial spillover), bölgesel dinamikler (regional dynamics) ve bölgesel yakınsama (regional convergence) dır.

Tablo 9. Yazar Kümeleri ve Anahtar Kelimeler

\begin{tabular}{|c|c|c|c|}
\hline Küme ID & Ölçek & Silhouette & Anahtar Kelimeler \\
\hline 0 & 20 & 0.771 & $\begin{array}{l}\text { Turkeyusa Relation } \\
\text { New Direction } \\
\text { Turkeys Relation } \\
\text { Main Argument } \\
\text { Bilateral Ties }\end{array}$ \\
\hline 1 & 19 & 0.859 & $\begin{array}{l}\text { Turkeys Relation } \\
\text { New Civilizational Discourse } \\
\text { Recent Arab Uprising } \\
\text { Geopolitical Orientation } \\
\text { New Middle Eastern Policy } \\
\end{array}$ \\
\hline 2 & 18 & 0.924 & $\begin{array}{l}\text { Spatial Spillover } \\
\text { Local Dynamics } \\
\text { Human Capital } \\
\text { İnnovation Process } \\
\text { Different National İnnovation Strategies }\end{array}$ \\
\hline 3 & 17 & 0.888 & $\begin{array}{l}\text { Regional Dynamics } \\
\text { Regional Development Disparity } \\
\text { State-Owned Bank } \\
\text { Developed Province } \\
\text { Creative Cities }\end{array}$ \\
\hline 4 & 11 & 0.996 & $\begin{array}{l}\text { Regional Convergence } \\
\text { Public Capital Stock } \\
\text { Turkish Region } \\
\text { Transportation Capital Stock } \\
\text { Conditional Convergence Model }\end{array}$ \\
\hline
\end{tabular}

Bölgesel kalkınma alanında Türkiye'de yapılan çalışmaların nitelik düzeyi ve ele aldığı konu başlıklarını belirlemek amacıyla, terim ve anahtar kelimelerin merkezilik değerleri hesaplanmıştır. Değerler tablo 9'da yer almaktadır. Derece değeri en yüksek, dolayısıyla en çok yayın yapılan ve atıf alan çalışma konusunun kümelenme (cluster) olduğu anlaşılmaktadır. Yakınlık değeri en yüksek çalışma konu ise şehir (city) başlığına aittir. Şehir konusu ve anahtar kelimesinin yer aldığ çalışmaların sahip olduğu bağlantıların yapısı, ağ içerisindeki diğer çalışmalara daha hızlı ve en kısa yoldan ulaşma imkânına sahiptir. Diğer bir ifadeyle, ağ yapı içerisindeki bilgi akışını izleyebilecekleri en iyi konuma sahiptirler. Şehir ve model konularını içeren çalışmaların yüksek yakınlık değerine sahip olması, şehir ve bölge planlama bölümlerinde yapılan çalışmaların iktisat ve uluslararası ilişkiler gibi diğer alanlarda yapılan çalışmalardan atıf alma/atıfta bulunma düzeyinin yüksek olduğunun göstergesidir. Ekonomik kalkınma (economic_development), sosyal sermaye (social_capital), kümelenme (cluster) ve büyüme (growth) kavramları yüksek aradalık değerlerine sahiptir. Bu kavramlar, İktisat, siyaset bilimi, şehir ve bölge planlama gibi farklı alanlardan yazar gruplarının birbirine bağlandığı ve aracı rol üstlenmektedir. 
Diğer bir ifadeyle, bölgesel kalkınma alanında yapılan çalışmalarda ekonomik kalkınma ve büyüme, sosyal sermaye ve kümelenme konularının en fazla etkiye sahip olduğu görülmektedir.

Tablo 10. Çalışma Konuları ve Kavramların Merkezilik Değerleri

\begin{tabular}{lclllc}
\hline & Derece & & Yakınlık & & Aradalık \\
Cluster & 3.422 & City & 208.000 & Economic_Development & 99.000 \\
Growth & 2.793 & Model & 208.000 & Social_Capital & 96.000 \\
Economic_Develpment & 1.830 & Globalizatin & 208.000 & Cluster & 69.000 \\
Sustainable_Development 1.711 & Future & 208.000 & Growth & 61.500 \\
İnnovation & 1.684 & Economic_Growth & 201.000 & Ínvestment & 36.000 \\
Regional_Development & 1.592 & Policy & 201.000 & İnnovation & 19.000 \\
Economic_Geography & 1.592 & Performance & 150.000 & Network & 19.000 \\
Investment & 1.500 & Competitiveness & 134.000 & Regional_Development & 7.500 \\
System & 1.367 & Network & 131.000 & Sustainable_Development 0.500 \\
Security & 1.211 & Foreign_Policy & 123.000 & Economic_Geography & 0.000 \\
\hline
\end{tabular}

Anahtar kelime ve kavramlara ilişkin ağ yapı haritasında, ağ içerisinde merkezilik değerlerine göre önemli konumda yer alan düğümler Türkiye (turkey), kümelenme (cluster), büyüme (growth) ve yenilik (inovation) olarak görülmektedir (Bkz. Şekil 4). Haritanın üst bölümünde yer alan düğümler iktisat (sol kısım) ve şehir ve bölge planlama (sağ kısım) alanlarını, alt bölümünde ise siyaset bilimi uluslararası ilişkiler alanlarına ait düğümleri yansıtmaktadır. Ekonomik kalkınma ve sosyal sermaye kavramları bu iki bölüm arasında aracılık rolü üstlenmektedir.

\section{Şekil 4. Anahtar Kelimelere Ait Ăg Yapı Haritası}

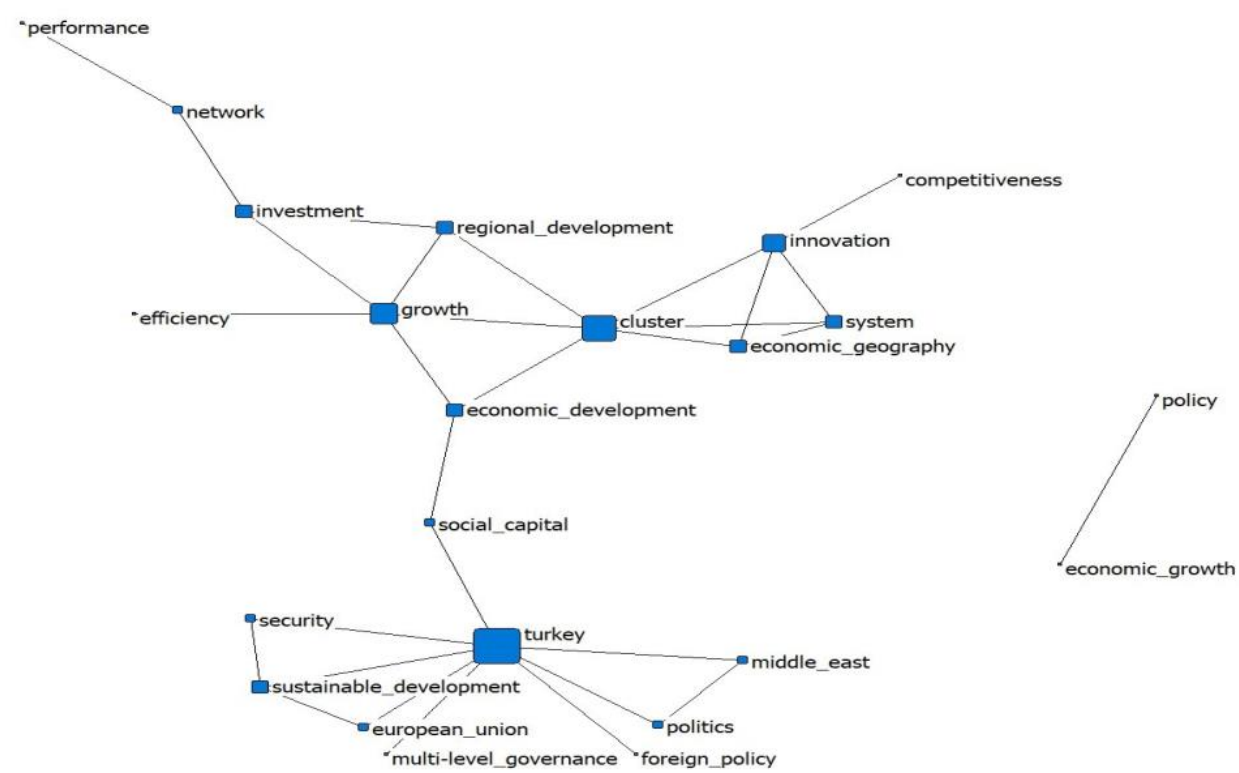




\section{SONUÇ}

Sosyal ă̆ analizi matematiksel grafik teorisini kullanarak sosyoloji, bilgisayar bilimleri, ekonomi, coğrafya gibi alanlardaki uygulamalarla çok disiplinli bir yaklaşım haline gelmiştir. Bibliyometri alanında da, bilimsel çalışmalarda kurum ve yazarlara ait işbirliği düzeyi, öne çıkan araştırma eğilimleri gibi nitelik yönünden değerlendirilmesini sağlamaktadır. Bu çalışmada, bölgesel kalkınma alanında yapılan Türkiye adresli yayınlar sosyal ağ analizi yöntemiyle değerlendirilmiştir. Türkiye'de yaşanan bölgesel sanayileşme ve gelir dengesizliklerine bağlı olarak, bölgesel kalkınma konusunun ilgi görmesine rağmen, atıf indekslerinde yapılan yayın sayısı 2008 yılına kadar yeterli düzey de değildir. $\mathrm{Bu}$ yıldan sonra hızlı artış gösteren yayın sayısı, yıllara göre de farklılıklar göstermekte ve yayın sayısının zaman içerisinde polinominal bir ilişkiye sahip olduğu görülmektedir. Yapılan yayınlarda kurumsal destek ve finansman da yetersizdir. Bölgesel kalkınma alanında önemli dergilerde yapılan yayın sayısı oldukça düşüktür. Aynı zamanda yayınların büyük bir kısmı etki değeri düşük dergilerde yayınlanmıştır. Kurum olarak öne çıkan üniversiteler büyükşehirlerde faaliyet gösteren yükseköğretim kurumlarıdır. En çok yayın ve atıf sayısına sahip yazarlar şehir ve bölge planlama ve uluslararası ilişkiler bölümlerinde görev yapmaktadır. Ekonomi bilimine ait bir çalışma alanında atıf indeksli yayın sayısının diğer alanlara göre düşük kaldığı görülmektedir. Bu nedenle, ekonomi alanında yapılan bölgesel kalkınma çalışmalarının, yurtiçi dergilerden ziyade atıf indeksli dergilerde yayınlanması çalışmaların gelişimine daha olumlu katkı sağlayacaktır. Bölgesel kalkınma çalışmalarına verilen kurumsal ve finansal desteklerin artırılmasıyla, atıf alma düzeyi yüksek dergilerde yayınlanabilecek içerik ve niteliğe ulaşması gerçekleştirilebilir. Bu alandaki çalışmalarda yerelde üniversitelerle kurumsal işbirliklerinin yapılması ve bölgesel kalkınma çalışmalarının ilgili alanlarda yaygınlaşması sağlanmalıdır.

\section{KAYNAKÇA}

Amin, A. (1999) “An Institutional Pespective on Regional Economic Development", International Journal of Urban and Regional Research, 23(2): 365-378.

Codal, K. S. ve Coşkun, E. (2016) “Sosyal Ağ Türlerinin Karşılaştırılmasına İlişsin Bir Ağ Analizi”, Abant İzzet Baysal Üniversitesi Sosyal Bilimler Enstitüsü Dergisi, 16(1): 143-158.

Ding, Y. (2011) "Scientific Collaboration and Endorsement: Network Analysis of Coauthorship and Citation Networks", Journal of Informetrics, 5(1): 187-203.

Dulupçu, M. A. (2006) "Bölgesel Politikalar Kopyalanabilir mi? Bölgeselleş(tir)me Karşısında (Yönetim) Karşısında (Yeni) Bölge(sel)cilik (Yönetişim)”, TEPAV, 233-255.

Eraydın, A. (2004) "Bölgesel Kalkınma Kavram, Kuram ve Politikalarında Yaşanan Değişimler”, Kentsel Ekonomik Araştırmalar Sempozyumu, 1: 126-143.

Göymen, K. (2005) “Türkiye’de Bölgesel Politikaların Evrimi ve Bölgesel Kalkınma Ajansları”, Yerel Kalkınma İçin Ortaklıklar içinde. İstanbul Politikalar Merkezi Yayını. 


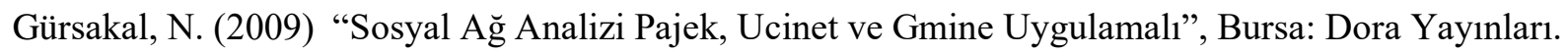

Keskin, H. ve Sungur, O. (2010) "Bölgesel Politika Ekseninde Yaşanan Dönüşüm: Türkiye'de Kalkınma Planlarında Bölgesel Politikaların Değişimi”. SDÜ Fen Edebiyat Fakültesi Sosyal Bilimler Dergisi, 21: 271-293.

Krugman, P. (1991) “Geography and Trade”, Cambridge, MIT Press, London.

Kumral, N. (2006) "Bölgesel Rekabet Gücünü Arttırmaya Yönelik Politikalar”. TEPAV Sempozyum,114.

Moulaert, F. ve Sekia. F. (2003) “Territorial Innovation Models: A Critical Survey”, Regional Studies, 37(3): 289-302.

Otte, E. ve Rousseau, R. (2002) "Social Network Analysis: A Powerful Strategy, Also for the Information Sciences". Journal of Information Science, 28(6): 441-453.

Özinönü, A.K. (1970) “Growth in Turkish Positive Basic Sciences”, 1933-1966. Ankara: Middle East Technical University.

Pritchard, A. (1969) "Statistical Bibliography or Bibliometrics", Journal of Documentation, 25(4): 348349.

Rueda, G., Gerdsri, P. ve Kocaoğlu, D. F. (2007) "Bibliometrics and Social Network Analysis of the Nanotechnology Field” In PICMET'07-2007 Portland International Conference on Management of Engineering \& Technology, 2905-2911. IEEE.

Scott, A. J. (2000) “Economic Geography: The Great Half-Century”, 24: 483-504.

Sevinç, H. (2011) “Bölgesel Kalkınma Sorunsalı: Türkiye’de Uygulanan Bölgesel Kalkınma Politikaları", Girişimcilik ve Kalkınma Dergisi, 6(2).

T.C. Başbakanlık, 2002/4720 Sayılı Karar, T.C. Resmi Gazete, Tarih: 22.09.2002, Sayı: 24884.

Tekeli, İ. (1996) Katılımdan beklentilerimiz Zaman içinde Nitelik Değiştiriyor Ada Kentliyim, No. 3, Sonbahar 1996, s. 23-24’ten aktaran Ökmen M., Özer B., (2007), “Küreselleşme-Yerelleşme Dikotomisinin Açılımları Üzerine Bir Tartışma. Küresel Esintiler ve Yerel Etkiler Sarmalında Türk Kamu Yönetimi”, (Ed. A.Yı1maz, Y. Bozkurt), Gazi Kitabevi, Ankara.

Thelwall, M. (2008) “Bibliometrics to Webometrics” Journal of Information Science, 34(4): 605-621. Yavan, N. (2007) “Bölge Bilimi'nin Gelişiminde Coğrafyacıların Rolü” Ulusal Bölge Bilimi/Bölge Planlama Kongresi, Bölge Biliminde Yeni Yaklaşımlar Bildiriler Kitabı 